\title{
TITUS SMITH JR. AND THE UNITY OF NATURE: ENVIRONMENTAL ADVOCACY IN EARLY 19 CENTURY NOVA SCOTIA
}

\author{
RICHARD H. FIELD* \\ Atlantic Canada Studies Program \\ Saint Mary's University \\ 923 Robie Street \\ Halifax, Nova Scotia, B3H 3 C3
}

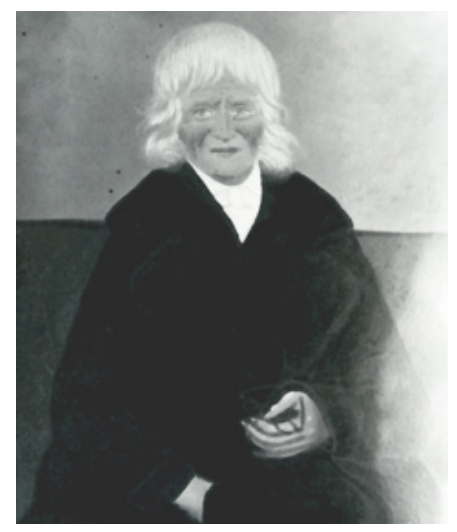

The only known portrait of Titus Smith, Jr., circa 1840. The attribution to Maria Morris suggests that she painted it while they were collaborating on the first part of the Wildflowers of Nova Scotia published in 1839. Smith holds eyeglasses in his left hand. Although listed in Norman Creighton's estate inventory at the time of his death in 1995, the present whereabouts of the painting is unknown.

\begin{abstract}
As scientists try to understand and predict the global consequences of climate change, the early environmental advocacy of Titus Smith Jr. (1768-1850) seems more relevant than ever. Smith's concept that industrial capitalism was disrupting the interlocking associations between humans and nature represented an alternate narrative that characterised the first wave of 19th century environmentalism in Nova Scotia. A study of Smith also enhances our knowledge about the beginnings of preservationist thinking and the environmental movement just prior to the era when science was not yet specialized and a single mind like Smith's could move between disciplines allowing each to inform the other.

Keywords: Titus Smith; ecological succession; environmental advocacy




\section{INTRODUCTION}

The life of Titus Smith Jr. bridged the end of the Enlightenment, the Romantic Era, and the beginnings of the Victorian Age. In the year Smith was born, Captain James Cook left on HMS Endeavour for his first voyage to the South Seas launching what Richard Holmes calls the "Age of Wonder," which ended with Charles Darwin's homecoming on HMS Beagle in 1836. Commonly regarded as the greatest ever voyage of exploration, the Admiralty ordered Cook to record the Transit of Venus across the face of the sun from Tahiti on 13 April 1769, and to search for the mythical Southern Continent (Gascoigne 2014). While Cook added to the map of the world with detailed surveys of coastal Australia and New Zealand, Joseph Banks, Daniel Parkinson, and other "scientists" (Wootton 2015) packed the storage holds, cabins, and the deck of the Endeavour with collections of exotic creatures, plants, and the art of never before encountered human societies. After his return, Banks had a display in his London apartment creating the first museum of Pacific culture combining, in a new way, natural history with human artifacts (Holmes 2009). Darwin would also return from his five-year circumnavigation of the globe with the key insights that underpinned 'natural selection' that became the most controversial theory of the Victorian Age. It changed the way humans saw themselves and their place in the world when he finally published $O n$ the Origin of Species in 1859.

Between these two celebrated voyages, European discoveries were shrinking the globe and creating new forms of knowledge as, for example, other expeditions led by Alexander von Humboldt to Spanish America from 1799 to 1804, and by Meriwether Lewis and William Clark across the whole of the North American continent between 1804-1806. They disclosed, to an ever-fascinated public, knowledge about wondrous lands, peoples, and bizarre life forms. Eventually, the natural and human-made curiosities collected on these various expeditions, which often indulged the pleasures of the wealthy, and turned room-sized collections into some of the first public museums.

This time was also the age of a new breed of experimentalists who shunned the rigid mathematical world and the mechanistic clockwork universe associated with Newton, Locke, Hooke, and Descartes, giving way to the notion of an infinite and mysterious natural realm waiting to reveal her secrets. The rise of geology and other earth sciences challenged the Christian stranglehold on creation that postulated that the 
earth and its organisms originated by divine fiat, with humans coming last, until a worldwide flood destroyed almost everything. Startling fossil discoveries, such as the first skeleton of a mammoth shown in the autumn of 1802 by the young American artist Rembrandt Peale at London's Pall Mall (O'Connor 2007), gave tantalizing glimpses of an earth history far older than the literal six-day event recounted in Genesis.

Inspired by discoveries in chemistry and astronomy, the Romantic revolution in science emerged with an imaginative intensity driven by an almost reckless desire to discover the dynamic laws, invisible powers, and cyclical transformations beneath the surface of the living world. This was immortalized, for example, in paintings by Joseph Wright of Derby (1734-1797). In his famous 1766 candlelit scene of "A Philosopher Lecturing on the Orrery," a student dutifully takes notes while two young children joyfully watch the mechanical motion of the planets around the sun. By contrast, Wright's 1768 "An Experiment on a Bird in an Air Pump" is immediate and disturbing. Here not only two young girls, but others watching the experiment, are clearly upset at the sight of the bird, in this case an exotic white cockatoo, convulsing and eventually dying in agony as the air is exhausted from the glass chamber.

While these types of paintings projected a sense of wonder and curiosity about the natural world, especially when confronting the mysteries of untamed nature, they also revealed a darker, more sinister side of science lurking in the Romantic ideal of the brooding genius. As Richard Holmes points out, this is one of the crucial conceptions-or misconceptions - of Romantic science. It was centered around the intuitively inspired moment of discovery that many writers and painters celebrated as either benefiting humankind, or like Mary Shelley, branded as a reckless Faustian idea. (Holmes 2009). Mary Shelley (1797-1851), the controversial muse of the "Age of Wonder," condemned the failure of science to save humankind that crystalized the Romantic conflict between sense and sensibility. In Frankenstein or the Modern Prometheus published in 1818 when Mary was only 19 , she merged science and fiction to forge a modern creation myth. Frankenstein evoked a scientific theology with man, not God, at life's epicenter.

The point here is that Smith too was a Romantic explorer and experimenter in search of knowledge about the natural world who was admired for his breadth of learning and a formidable memory 
that allowed him to recall the smallest of details. He packed his life with incessant work and believed that knowledge had to be shared, exchanged, and made available to everyone. However, Smith was also a man of diverse interests. His early life in Nova Scotia was defined by his government sponsored provincial surveys in 1801-1802 for Lieutenant Governor Wentworth to inventory natural resources (Field 2013). However, in the last decades of his life Smith employed his unremittingly natural theology to counter the two emerging giants of the $19^{\text {th }}$ century - capitalism and industrialization - with an alternate environmental narrative. In many respects, Smith's life is a Janus-faced lens that looks two ways at once-back to the origins of the environmental movement-and forward to all those current environmental advocates who echo Smith's preservationist efforts in calling for the conservation and stewardship of nature. They called for conservation and the stewardship of nature. Becoming a fierce opponent of industrial capitalism that exploited nature for profit, Smith was an early naturalist who envisioned the human and natural realms as integrated halves of a single whole. He saw the world as an expression of God's design. For Smith, God was not a separating agent between humanity and nature, but a unifying authority. The primal forces of creation offered an image of both division and connection, a divine bridge between natural and human. Smith, therefore, saw human need and purpose linked to nature. For him, the natural world and an environmental consciousness conditioned human well-being and sustainability.

\section{SMITH IN AMERICA}

Titus Jr., was the first child of Reverend Titus Smith and Damaris Nash nee Waite, whom Smith married while he was serving as a pastor in a small church in West Suffield, Connecticut. The younger Titus was born in Granby, Massachusetts on 4 September 1768, one month after Cook departed from Plymouth, England. By age three, Titus exhibited the intellectual powers of eidetic memory often attributed to child prodigies. By age four, the pastor's young son was an adept reader. Even today, such gifted children often receive early education like the young Smith. He was given accelerated enrolment into a private school at New Haven run by Daniel Humphreys, a fellow Yale alumnus of his father (Piers 1938). Here the classic curriculum and 
disciplined environment sparked the boy's intellectual and imaginative powers. Titus was proficient in Latin by age seven; translating the classics at age 12. By 16, when his father presented his son with a gift of the complete plays of Shakespeare, the teenager apparently not only read the Bard's dramas in one sitting, but thereafter could recite entire scenes.

In the Smith household, intellectual life flourished in the humanist tradition. Reading aloud was proper conduct to instruct children and benefit people unable to learn in other settings. Beyond these practical benefits, recitation was also a mark of civility and cultivated taste that enhanced the mental culture of refined households (Bushman 1993). The young Titus recited Greek and Latin verse, languages also familiar to his three siblings: Rebecca, born in 1771, Sylvester in 1773, and William in 1777. Years later, his brother William told how Titus relished the discourse that inevitably erupted on political, philosophical, and religious subjects when well-read neighbours visited the house. He also remarked that "his earliest desire appeared to be to perfect himself" (Lawson 1972), an aspiration clearly noticeable in Titus' personality.

With the beginning of colonial hostilities against England, the elder Smith's decision to remain loyal to the crown and reaffirm his conscientious objection to violence initiated a period of turmoil for his family. Although Titus sympathized with the rebellious colonies seeking independence, not even an appeal from George Washington to supply gunpowder to his troops changed his views (Lawson 1972). In 1775, after refusing Washington's request, Smith signed a petition outlining Sandemanian religious convictions against any form of opposition to the King's government. Forced to leave New Haven, Titus and his family took refuge with other Loyalists inside the British lines at Bushwick, one of the original six towns comprising Brooklyn, New York, and chartered in 1661. It was here in August 1779, in her 42nd year, that his wife Damaris fell ill and died.

Having four children between the ages of two and 11, Titus quickly married Lydia Barstow, whom Smith was undoubtedly acquainted with as a member of the Sandemanian church. Intermarriage among followers was common. His father's support of the King also led to his sons removal from Humphrey's School in New Haven, and permanently closed the possibility of his entering Yale in his father's footsteps. The 11-year-old's education, that now fell to his father and other knowledgeable adults, apparently did not pause or waver. By his 
next birthday, Titus was translating the Latin authors and progressing in Greek (Piers 1938). In 1783, Titus and his family departed the newly formed American nation. In the company of his old friend Theophilus Chamberlain, the British evacuated the Loyalists from New York to Nova Scotia. There seven years earlier the Sandemanians among the Boston Loyalist refugees had established a church in Halifax located on the north side of Prince Street between Barrington and Granville. Smith Senior presided as an elder along with John Howe, the father of the reformer Joseph Howe (Beck 1982, Stayner 1951).

By the time the 15-year-old Titus landed on the shores of Nova Scotia, he had witnessed momentous civil and political unrest that fundamentally changed the course of history. Thus, as a teenager, Smith saw the impact of these formative events and learned about civil disobedience and political dissent from his father. These influences emerged later in life when he publically expressed unpopular views about class struggle, materialism, and industrial capitalism.

\section{SMITH IN HALIFAX, PRESTON, AND DUTCH VILLAGE}

To a viewer standing on the deck of a ship entering Chebucto Harbour in 1783, three features dominated the Halifax skyline-the wind-whipped pennants flying from the towering signal masts of Citadel Hill, the spire of St. Mathers, and the steeple of St Paul's Anglican Church. These structures symbolized the ability of the Admiralty and Board of Trade and Plantations to project into the wilderness of Nova Scotia a settlement that validated British control over territory granted under the terms of the 1713 Treaty of Utrecht. Although British colonies were not exact replicas of English towns, or of each other, a familiar set of laws, political institutions, and religious belief inextricably linked them to Britain. These institutional faculties were supported by a replicated set of recognizable material traditions and served as the defining backdrop to Britain's imperial ventures, each working harmoniously, to make the world England.

Halifax, once part of a powerfully evocative projection of a farflung British Empire founded to help secure Britain's destiny in North America, was not a particularly inviting place when the Smiths, their friend Theophilus Chamberlain, and other Loyalists arrived from New York on board the transport Nancy in 1783. Many Loyalists, 
who thought they were going to another Boston, Philadelphia, or New York, albeit smaller in scale, were sorely disappointed at the condition of the colony. For most, however, their dismay was not pressing, owing to the impoverished state in which many found themselves. In a letter written 20 November 1783, Governor Parr wrote, "upwards of 25,000 Loyalists have already arrived in the Province, most of whom, with the exception of those who went to Shelburne, came to Halifax..." (Akins 1973). This sudden influx increased the population of the town by three times. "Typically, the refugees were poor, desperate, and increasingly disillusioned with the prospects facing them in towns such as Halifax" (Fingard, Guildford, and Sutherland 1999). Much of the housing in Halifax dated from its founding, many had low-gabled roofs with dark interiors dominated by massive fireplaces to ward off winter wind and cold. The streets were crowded, food scarce, and crime prevalent. Arriving with few personal belongings, the once productive, respected families, and individuals fell into despair and poverty with only idleness to occupy their days and nights. Although there were enterprising Loyalists who built refined and commodious dwellings by 1791, many moved elsewhere in the Province or returned to England.

The Smiths' were no exception. Within a year of their arrival, they moved to the Township of Preston where 162 Loyalists received lots after Theophilus Chamberlain mapped it in 1784 as deputy surveyor under Charles Morris. The Township contained 56,772 acres with 32,000 acres granted to the Loyalists and the remaining part was reserved for future use. In 1791, Lieutenant John Clarkson, one of the central figures in the abolition of slavery in England and the British Empire at the close of the 18th century, arrived from London. His aim was to help remove black settlers to Sierra Leone. Clarkson, who visited the Smith farm on 12 October, made an entry in his diary about his stopover. He called the elder Smith an "honest gardener," and "excellent botanist," and commented that he used part of his garden for botanical experiments, and that Smith showed him some of the maple trees he had "refined" (Lawson, 1972).

Experimental gardens, like the one first established by the Smiths at Preston, were essential to meet the demands of local gardeners for the vegetable and flowers seeds that would thrive in Nova Scotia's soil and climate. When the Smiths moved to Dutch Village in 1796, father and son continued their Preston efforts to produce viable varieties of vegetable and fruits. By 1830, through advertisements, Titus Jr. made 
available to farmers, gardeners, and overseas correspondents local seeds of the most common vegetables, along with collections of Nova Scotia's indigenous plants. In a letter written at Windsor on 9 April 1839, the unidentified correspondent asks Smith to send to Three Mile House via Mr. Jordon, the mail coachman, "roots of the Indian plant, called blood root, the potato plant from Newfoundland, and the other blue snap-dragon" (PANS). In another letter from Windsor dated 26 August 1839, Thomas King requests that Smith send to a friend in Europe "all the forest seeds of our trees \& shrubs" (PANS). It is unknown if Smith filled Mr. King's large request. Smith also introduced into his own garden, and those of friends, indigenous plants he collected on his journeys. Piers states that as early as 1822 , Smith planted a large variety of native trees on his grandfather's property that included Red baneberry (Actaea rubra), white Bloodroot (Sanguinaria canadensis), and American Spikenard (Piers, 1938).

Titus Smith Jr. continued the long tradition of botanical exchanges between North America and Britain by acting as an agent to supply indigenous and acclimatized plants, and local seeds from Nova Scotia to botanical enthusiasts in England and Scotland. The earliest correspondence dated 30 May 1825 from Mr. Charles Manley thanks Titus for the box of plants forwarded to him by Mr. Franklin (Norman Creighton Fonds). Manley notes several of the specimens took root and thrived considering the season was against them and adds that he would appreciate Smith resending him the plants that perished. Manley also requested that Smith send him some new species and enclosed a list of Latin and common names for over 50 plants, trees, and shrubs including: Mountain Pine, Diervilla, Winterberry, Ilex, Pinus nigra, Viburnum, and Aralia racemosa.

Smith also exchanged seeds and plant specimens with the Scottish botanist Robert Graham (Norman Creighton Fonds). In a letter dated Edinburgh 29 March 1839, Graham thanks Smith for his sizable contribution of dried plant specimens for his Herbarium. Graham sent Smith a new edition of Persoon`s Synopsis plantarum, first published in two volumes between 1805 and 1807. Graham was an M.D. and a botanist appointed in 1820 as the first professor of Botany at Edinburgh University. Although Graham published a number of botanical papers, his Flora of Great Britain remained incomplete at the time of his death in 1845. However, he did successfully develop the Edinburgh Botanical Garden, which may be the reason he contacted Smith to obtain plant specimens for both his garden and Herbarium. 
Experimental gardens, botanical correspondence, travel narratives, and shipments of seeds and plant specimens all characterized the mediums of exchange between colonial North America and Britain. There was an ever-demanding and curious public seeking knowledge about the natural history of the Atlantic World, which Susan Scott Parrish suggests led to the very birth of modern curiosity itself (Parrish 2006). These interactions helped to establish the reputation of colonial correspondents such as Smith within London's natural and philosophical circles that saw his lecture on "The Natural History of Nova Scotia” published in 1835 in London's The Magazine of Natural History.

Two events prompted the elder Smith to sell his Preston farm and move to Dutch Village in 1796. First, all of the elder Smith's children except Titus returned to Connecticut and secondly, over 500 "Maroons," arrived from Jamaica to work on the Halifax fortification. Their arrival in July of that year caused discontent between Governor Wentworth and Colonel W. D. Quarrel of Jamaica who was in charge of the Maroons. Smith Sr. seemingly took advantage of the planned purchase of land in Preston for their settlement and sold much of his Preston farm to Colonel Quarrell on 17 August 1796. Less than two months later, on 22 October, Smith purchased from Martin Wagner a small house, farm, and woodland of 50 acres in Dutch Village. This was originally, lot number 1, granted to Frederick Kohl in 1763. Wagner and Kohl were part of the group of German farmers who wanted to return to Halifax after moving to Lunenburg in 1753, and who successfully petitioned the government for land that stretched along the western slope of Chebucto Basin (now Bedford Basis). On 8 April 1763, The government granted lots of 150 acres to nine settlers, with three more lots added in 1765. In 1768, about fifty Germans had settled in what became Dutch Village (Bell 1961). The farm and gardens purchased by his father would become Titus Jr.'s private retreat from the public world; a place where he conducted his naturalist activities, departed from for his provincial journeys, and where he continued his agricultural trials after his father's death in 1807. Dutch Village was, until his death in 1850, Smith's place of solitude, experiment, and research where he developed his ideas about environmentalism, and manufactured the impressive body of knowledge that earned him the famous title of "the Rural Philosopher of Dutch Village" from Joseph Howe in 1828. 


\section{SMITH AND THE HALIFAX MECHANICS' INSTITUTE}

The proposal to establish a Mechanics' Institute, put forth as early as 1827 by the editors of "The Colonial Patriot," the "Novascotian," and the "Acadian Recorder," was intended to educate the populace and prepare artisans and journeymen for the uncertainties posed by industrialization through public instruction in the mechanical and applied sciences (Fergusson 1960). When Joseph Howe rose to deliver his inaugural address to the members of the newly formed Halifax Mechanics' Institute on Wednesday evening, 11 January 1832 he stated, "In forming this Institute, its members were not unmindful ...how much the body-politic might be facilitated or retarded by the intelligence or ignorance of the handicraftsmen" (Howe 1832).

On 5 March 1834, Smith presented the first of two lectures before the Halifax Mechanics' Institute where for the first time he outlined his ideas about recurring changes in nature. In the first talk on "Mineralogy," he told his audience that the earth's landscapes formed from a sequence of previous landscapes. "From all I have observed, I am compelled to believe that we have no proof that any mass of rocks have existed in this province in its present state since creation. I believe that we have fertile lands formed from materials which were once rock; that we have masses of rock which were once earth; that there have been changes within the rocks as well as on the surface; and that these changes will continue till they are brought to a conclusion by the last great change" (Smith 1834).

Smith's observations about these recurring changes in the landscape were aligned with early $19^{\text {th }}$ century principles of "natural theology," particularly the views expressed by William Paley (1743-1805) in his bestselling Natural Theology: or, Evidences of the Existence and Attributes of the Deity, collected from the Appearances of Nature first published in 1809. Paley's suggestion that divinely appointed forces guided the growth of bodies and the formation of matter did not undermine the idea of secondary changes that occurred in nature over time from first cause (Genesis) to final cause (Revelations).

Less than one year later on the evening of 14 January 1835, Smith presented to the members of the Halifax Mechanics' Institute his second and most important lecture. Titled "The Natural History of Nova Scotia," it was subsequently published in the December issue of London's The Magazine of Natural History, as "Conclusions on 
the results of the Vegetation of Nova Scotia and on vegetation in general, and on man in general, of certain Natural and Artificial Causes deemed to actuate and Affect them." This lecture seemingly comprised two opposite concepts that were in fact, for Smith, halves of the same whole. The first outlined Smith's Theory of Ecological Succession that Evile Gorham, who resurrected Smith's theory in 1955, appraised as one of the first major contributions to plant ecology in North America (Gorham, 1955). The second questioned the wisdom of a society abandoning its agrarian economy for one built around machines and mechanization. Smith objected not only to the sense of power conveyed by machines of industry over nature, but also to the creation of a working class dependent on others for their livelihood and not on the products of their own labours.

As if to assure his audience that God was still at the helm of his ideas, Smith began his lecture before his Institute audience on that January evening by conjuring the God of Creation. "For, rough and rude as our forests appear, they form a portion of the 'garden of God.' In all their various productions, there is nothing superfluous or out of place" (Smith, 1835). In doing so, Smith was reaffirming for his listeners the hierarchical structure of the Great Chain of Being (scala naturae), derived by the Medieval Christian church from the classical thought of Plato and Aristotle. They ranked all life from its primal elements to God. Smith knew from his own observations, however, that the interrelationships between species in nature were much more complex. Beginning during his provincial surveys, Smith began to notice that disruptions of ecological communities caused by natural or human events resulted in new associations between species within a given ecosystem. Nature was not, as thought, a divinely passive hierarchical system, but a world where living organisms influenced one another in surprising ways, which Smith revealed to his audience in meticulous detail by explaining that within any ecosystem every species has a set of environmental conditions under which they will thrive and reproduce most optimally.

What mostly concerned Smith, however, was secondary ecological succession caused by human harvesting, colonization, and industrialization that violently and unnaturally disrupted the balanced composition of ecological communities. For Smith, this was the point. Machines gave humans, as the dominant species, unchecked power over any ecosystem to harness nature as an industrial resource. The consequence of this union between "man and machine" was not only causing social 
and environmental imbalances but also humanity's abandonment of their role as stewards of nature. Smith also understood that generating an environmental discourse over resource exploitation could not take place without debate about capitalism and industrialization. Thus Smith ended his lecture with a series of searing comments. It was as if Smith finally had had enough. Clearly vexed, he publically judged those responsible. ["A] constantly increasing evil is to be found in habits of unbounded luxury and extravagance, which have turned the labour of multitudes from producing the necessities of life, to furnishing articles of luxury for a few very rich individuals" (Smith 1835). Smith further stated, "In every part of Europe manufactories appear to be increasing. The business is overdone; markets cannot be found sufficient to absorb the immense quantities of goods. The motive appears to be found in the great fortunes that some capitalists have acquired" (Smith 1835).

Smith pressed on with remarks that clearly foreground modern concerns about the increasing inability of the planet to feed the world's population. "There is a general complaint of the great and increasing distress of a superabundant population, who cannot find employment by which they can support themselves. This distress has reached such a height...that opposite parties are predicting a bellum servile, or war of the servants against the masters; and it has seriously been proposed to enact laws to prevent a portion of the labouring class from marrying...who seem to fear that [the earth] may fail to produce sufficient food for its inhabitants" (Smith 1835). This view reflects Thomas Malthus' famous treatise An Essay on the Principle of Population first published in 1798 , where he stated that unchecked population growth increases in a geometrical ratio while the power of the earth to produce subsistence increases only arithmetically. Prophetically, Smith concludes his remarks by stating, "The necessities of life are drawn principally from the culture of the earth. Money, or what we call wealth, is the power of commanding this labour, but this power is not always wisely applied. From habit, men sometimes continue the business, which formally was profitable" (Smith 1835). For Smith, the idea that machines and mechanization would foster human progress and lead to greater happiness and improvements in society was an illusion. Smith chose instead to infuse his remarks with a sense of dismay at the loss of the dignity, freedom, and independence that comes from the products of one's own labour. 
We will never know how Smith's views were received. Did he use his reputation as a naturalist and philosopher to present his irreverent ideas before an Institute audience he knew would include wealthy merchants and politicians, some of whom represented the pinnacle of 19th century Nova Scotian society? After all, his comments represented a deep defiance of established economic and political policies and drove forward his argument that ignoring our obligation as stewards of nature would have dire consequences, which he summarized. He summarized in one of his more famous statements near the end of his lecture: "Whenever man neglects the dictates of nature, he is sure to suffer" (Smith 1835).

Smith's final lecture to the Halifax Mechanics' Institute on "Painting" coincided with his collaboration with Maria Miller to produce the first Nova Scotia Florilegium. Although Smith would live for another 14 years, what distinguished the writings that emerged from this period centered on his continuing advocacy for agricultural improvement. This involved his work with the Central Board of Agriculture after becoming secretary in 1841 , at age 72 . In that capacity, Smith contributed weekly articles to The Acadian Recorder on farming practices until his death in 1850. As Terry Punch stated, his physical energy and intellectual abilities involved him in so many public activities they are difficult to recount. "He selected and planted the original rectangle of trees which surround Province House...wrote petitions, served as road overseer...was active in the Horticultural Society... gave evidence before the Durham Commission, and lectured at the Mechanics' Institute" (Punch 1978). All this while farming, surveying, experimenting with seeds, and raising fourteen children. Despite his success, however, Smith's contemporaries thought his life difficult.

Throughout his involvement with the Mechanics' Institute as well as the Halifax Scientific and Literary Society, Smith clearly supported the education of the populace and democratic notions about a people's science. For Smith, it seems only useful knowledge, not profit, material gain, or inherited privileges supplied an individual and a nation with true power. On 13 February 1836, the Acadian Recorder reprinted Smith's lecture on "Education" read before the Institute on 11 February clearly outlining his egalitarian attitude toward education, the working class, and a nation's prosperity. "If all the inhabitants of a country were taught reading, writing, and the first rules of arithmetic, and then permitted access to books containing nearly all the useful knowledge which man has acquired, they must necessarily be more 
prosperous than the inhabitants of a country possessing equal advantages of nature, but closing the sources of knowledge to the greater part of its population" (Smith 1836a).

It is interesting that Smith equates knowledge with the power to make great nations, citing England and America as examples, but only if the "greatest portion of useful knowledge is...made most accessible to all" (Smith 1836a). In other comments, that reflect his own selfeducation, he shuns college-based learning. "But if all are taught to read and works containing the most useful knowledge placed within their reach, they who are qualified by nature...will, without other assistance, acquire more knowledge than the majority of those who are sent to colleges" (Smith 1836a). Later he states that the poor who have access to the power of knowledge in libraries, and are gifted with superior natural abilities, can acquire as much information about art and science as they would have done in college. These comments are indeed surprising coming from a man who was educated in the humanist tradition and who mastered Greek and Latin at a young age. That is, until one considers the fact that his father's opposition to the American Revolution and loyalty to the Crown lost his son the opportunity to attend Yale. As a result, all of his life Smith carried the label of being "self-taught."

What made Smith so different from his provincial counterparts was his fluid mind and an interdisciplinary approach that informed his ability to grasp the importance of humanity's interconnectedness to nature. This is one reason why Smith objected so passionately to the exploitation of people and the natural world for profit. Believing that industrial development and capitalism turned the environment into a site of conflict between mind and nature that led to the oppression of a nation's people, Smith also advocated for universal education particularly for the poor. He also encouraged the purchase, growing, and manufacture of local products rather than relying on imported manufactured goods.

"We are, during our long winters at Halifax, burthened [sic] with a great number of poor people, able and willing to work at any rate of wages, but who can find no employment. Yet we purchase palmetto hats from our neighbours, instead of importing the leaves and making them, as they do-we use a great number of nets, but ought to import the hemp only, and make them here. We lack heads in proportion to our hands...." (Smith 1836a). 
Smith hoped that the goals of the Institute to bring science to the people, would succeed beyond the limits of Halifax, and spread a larger portion of useful knowledge through the province. Indeed, it did. Mechanic' Institutes established in other Nova Scotian towns from the mid-1830's included Sydney (1837), Antigonish (1840), Liverpool (1841), and Windsor and Dartmouth (1842). In Pictou, however, because of the early influence and work of Rev. Thomas McCulloch, a subscription library was founded in 1822, that like the Halifax Mechanics' Institute, fostered scientific pursuits through a variety of public lectures and demonstrations.

\section{THE UNITY OF NATURE}

Romanticism emerged from enlightenment rationalism with a desperate sense of alienation from nature. For the romantics, nature could only be understood by turning inward. English romantics such as Samuel Taylor Coleridge and American Transcendentalists such as Ralph Waldo Emerson declared that humankind had once been one with nature (Wulf 2015). While some romantic natural philosophers believed in the importance of close observation, classification, rigid measuring, and data collection, they also embraced individual perception and imagination as being equally important.

Here is the event horizon between the Age of Reason with its rigid model of predetermined cosmic order from which humanity cannot escape, and the Romantic Era that saw nature as the antithesis of a hierarchical society rooted in institutionalized practices of thought. No poet better epitomized this mystical relationship than William Wordsworth did. These Romantic sensibilities were part of a Wordsworthian tradition identified with individual consciousness and contemplation where nature provoked a state of imagination that led to a higher self-awareness. This is what Scott Hess calls the ecology of authorship associated with a radically profound, and highly personalized relationship with nature (Hess 2012). The ecology of authorship disconnected the individual from specific places and environments. Leisurely travelers experienced nature through detachment and sensual immersion, or as Scott Hess explains, "the ability to transcend [ones] own flesh and blood into a kind of disembodied aesthetic consciousness" (Hess 2012). 
Smith's environmentalism, however, was a tangible, earth under the fingernails ecology of community where people experienced nature through connection and direct engagement with their local environment. While echoing Michael McGinnis's (1999) bioregional view that an ecology of community is a place where the environment is shared through participative human practices of localized material, political, and economic systems (Hess 2012), there was, however, an added dimension to Smith`s ecology of community. Humans needed to submit to God's authoritativeness by uniting communitarianism with humanities duty to protect the bounty of nature for the long-term welfare and survival of humankind.

What Smith sought was what Ralph Waldo Emerson called an "apocalypse of mind" (Walls 2009) that folded nature back into the mind of God as creator, and then into human consciousness as part of that creation. In many respects, Smith's views represented a form of pantheism that integrated the divine and humankind in nature. Smith constantly uses a language in his lectures and articles to impress upon his audience the importance of this link which was often dismissed because of its fundamental Christian overtones. However, one wonders if his comments were any different from those Romantic writers who similarly recognized in nature the majesty, power, and perfections of the creator?

Clearly, Smith's ideas about the interconnectedness of humans and nature, brushed against the grain of prevailing opinions. His views were neither brooding, dark, or reckless but imaginative and objective, grounded in two realities both bound by moral authority - one resided in God, the other in human consciousness. He understood that, as agents of free will, humans often chose to ignore what they knew was morally right and acted in opposition to natural and human law. In these instances, self-preservation often overrules acts of kindness and obligation to others resulting in antisocial behaviour towards those less fortunate. For Smith, the worst examples of this were profit-driven economic and political systems that increased the opportunities for individuals to forget themselves. Based on false notions of status, the power of moral example diminished as people turned from the products of their own soil and industry to a form of individuality which was marked by unrestrained acquisitiveness, driven by desires for material wealth and status.

The idea that the sacred pervaded all of nature also informed every aspect of Smith's life. There was a beautiful harmony to 
Smith's world determined by "the Great Cutivator. His ecological advocacy was not only about connection but also about knowledge. Without knowledge, there was no understanding of humankind's sacred obligation to maintain the ecological integrity of the planet. In Smith's lecture on "Biology" to the Halifax Mechanics' Institute reprinted in the 20 February 1836 Acadian Recorder, he stated that humankind did not understand the workings of the natural world and its importance to the future of humanity. "The Operations of Life, the animating principles of all organized bodies, are perpetually before our eyes, yet there is nothing that we less understand" (Smith 1836b).

Importantly, Smith's ideas were not isolated from the mainstream environmental thought of his day. His concerns about the growing conflict between humans and nature paralleled the thinking of other naturalists during the $19^{\text {th }}$ century. They deplored the tragic destruction of forests and the exploitation of natural resources to meet the demands of industry. One of those individuals was Alexander von Humboldt (1769-1859), who like Smith believed "to scar the face of nature is to scar the people it nourishes" (Walls 2009). For Humboldt, the external world and the internal world of feeling were inextricably linked (Wulf 2015). There is no evidence to indicate that Smith was familiar with Humboldt or his writings, although they were available in some of the newly established subscription libraries in Halifax. Humboldt's Personal Narrative of Travels to the Equinoctial Regions of the New Continent, During the Years 1799-1804 published between 1814 and 1829 was listed in the 1831 catalogue of the Halifax Library to which Smith was a subscriber. The 1835 catalogue of books for the Cambridge Military (Garrison) Library also listed this book in their collection as well as Humboldt's extraordinary English edition of his two volume Researches concerning the institutions and monuments of the ancient inhabitants of America: with descriptions \& views of some of the most striking scenes in the Cordilleras published in 1814.

Laura Dassow Walls sees Humboldt as standing at the head of today's ecological movement, established by such figures as Henry David Thoreau, George Perkins Marsh, and John Muir. "He succeeded in bringing into being a discourse, a way of speaking, about nature that we now call 'environmental': namely, a planetary interactive causal network operating across multiple scale levels, temporal and spatial, individual to social to natural, scientific to aesthetic to spiritual" (Walls, 2009). Humbolt was born one year after Smith in 1769. When in (1801-1802) Smith carried out his provincial surveys 
for Wentworth, Humboldt was already two years into his five-year expedition (1799-1804) to Spanish America. Both men also saw, during their lifetime, how nature was being remade by colonial imperialism, global capitalism, and the beginnings of the industrial revolution. Eventually what began as a dialogue about nature and humankind's relationship to it became in 1866 the science of ecology, a word first coined by Ernst Haeckel.

There are parallels in the thinking of both Smith and Humboldt. In particular, both men were concerned by deforestation caused by agricultural and industrial development. "Humboldt was the first to explain the fundamental functions of the forest for the ecosystem and climate: the trees' ability to store water and to enrich the atmosphere with moisture, their protection of the soil, and their cooling effect. He also talked about the impact of trees on the climate through their release of oxygen. Humboldt insisted that the effects of the human species' intervention were already 'incalculable,' and could become catastrophic if they continued to disturb the world so brutally" (Wulf 2015). As Gorham points out, Smith too was equally concerned about the destruction of trees and forests by human actions and by the fires necessary to clear the land for the increasing number of human inhabitants. (Gorham 1955).

As Smith states (1835), "This process of nature was favoured by the habits of the Indians, who carefully avoided setting the woods on fire. But the great influx of inhabitants in 1783 produced, in the course of a few years, a complete change in the appearance of the forest. A great number of new settlements were formed. The fires necessary for clearing the land were communicated to the spruce thickets, and spread frequently as far as they extended. The profusion of herbage which followed the fire, for a time furnished a pasture for cattle. This failed in three or four years. The next dry season the fire was rekindled, for the purpose of renewing it, which it would do in a less degree. Raspberries, French willow, and other vegetables would appear upon part of the ground, but of inferior growth. The roots of the spruces and balsam fir spread horizontally, and take but slight hold of the ground. Being loosened by the sinking of the turf, they are overthrown by every wind, and furnish fuel for successive fires, which are usually rekindled every dry season by design or negligence till...the ground becomes so much exhausted, that it only produces a growth of healthy shrubs. 
There is little question that Smith attempted to create for the first time in Nova Scotia an environmental discourse about the relentless pace of industrial and agricultural progress. This was based on his belief that nature was not just a background for human development but essential to humanity's well-being. Such sentiments were clearly counter-intuitive to early $19^{\text {th }}$ century ideas about humans dominating nature. Humankind, after all, was divinely destined to make the natural world better by civilizing the wilderness through cultivation and improvement to create orderly fields, cleared forests, neat villages, and productive landscapes. During Smith's lifetime, human progress depended on nature being "conquered," not defended.

\section{CONCLUSION}

With biodiversity in crisis everywhere, recovering Smith`s vision of a natural world that was no less than the collective phenomena of nature and humankind, where a violation in one recoiled in the other, deepens our knowledge about the history of early environmental advocacy in Nova Scotia. Smith's views on the environment are not old-fashioned- since everything for Smith was about connection. He clearly perceived in nature a deeper reality that for him represented the face of a higher truth. Without it, Smith saw the world adrift in soulless materialism. As Gorham claimed, Smith's science was truthful and founded on measurable observations and inductive reasoning. This also grounded his environmental and social thinking. Thus, when Smith mapped out his theory of ecological succession, he clearly implied that the process of adaptation and disruption also applied to human communities. Clearly, in his writings, Smith linked the human causes of ecological change-namely capitalism and industrialization - to the upheavals he witnessed in society. They were laying the groundwork for a society dominated by an evolving breed of entrepreneurs, industrialists, and financiers.

Smith knowingly participated in the practice of acquiring knowledge in which experiment, observation, and classification provided the basis for a holistic system of explanation that increasingly marked the shift to modern ways of looking at the world. For Smith, humans needed to listen to the voice of nature to ensure the survival of their community through commitment and interconnectedness. Communities stripped of this affiliation due to their excesses against nature or their 
extravagant reliance on worldly goods, whose ownership glorified the individual over the duties we owe to each other, were relegated to failure. Just as Smith forewarned, the specter of humankinds accumulated transgressions against nature haunt the twenty-first century (Doyle 2014). We are witnessing the complete collapse of ecosystems that go back thousands of years, as irrevocable economic and industrial consequences overwhelm the environmental integrity of the planet. Ironically, Smith's ideas about unity in diversity and the interconnectedness of all living things being critical to the survival of humans and nature, seem almost as radical today in the minds of some politicians and company CEO's as they were during his lifetime.

Smith, like his father suffered from a liver ailment, experienced an attack of "jaundice" in the fall of 1849. It is likely that father and son suffered not from Jaundice, that is caused by bile pigments accumulate in tissues, resulting in yellowing skin, but from Hemochromatosis. The latter is one of the most commonly inherited diseases in America among people of Western European descent. It is caused by an accumulation of iron in the liver. The symptoms include joint pain, fatigue, weight loss, abdominal pain, and a "bronzing" of the skin, the latter being the reason why in the nineteenth century this disease was often misdiagnosed as jaundice. Smith took more than the usual amount of exercise to ward off the condition and hide the symptoms from his family. Despite his efforts, and generally strong constitution his liver failed.

Titus Smith Jr. died at the age of 81 on January 4, 1850, on the anniversary of his marriage to his beloved Sarah 47 years earlier. He was interred in a small family burying-ground overlooking Bedford Basin, where his father, stepmother, and some of the early Dutch Village German settlers were also allowed to bury their dead. Sometime after 1866, someone erected a six-and-a-half-foot grey granite obelisk simply carved with his name, the date of his death, and his age.

Acknowledgements: Funding was provided by a SMUWorks Grant from Saint Mary's University and the Gorsebrook Research Institute for Atlantic Canada Studies. Thanks go to Dr. Peter Twohig and Dr. John Reid. 


\section{LITERATURE CITED}

Akins, B. (1973). History of Halifax City. Mika Publishing, Ontario. 85.

Beck, J. M. (1982). Joseph Howe: Myth and Fact. Saint Mary's University, Halifax. 11, 19.

Bell, W. (1961). The Foreign Protestants and the Settlement of Nova Scotia. University of Toronto Press, Toronto. 622-623.

Bushman, R. (1993). The Refinement of America: Persons, Houses, Cities. Random House, New York. 280.

Doyle, A. (2014). Reuters News Service. 21 August.

Fergusson, B. C. (1960). Mechanics' Institutes of Nova Scotia. Public Archives of Nova Scotia, Halifax. 44.

Field, R. (2013). Colonizing Nature: Titus Smith Jr. and the Making of Nova Scotia, 1800-1850.Land and Sea: Environmental History in Atlantic Canada, edited by Robert Summerby-Murray and Claire Campbell. Acadiensis Press, Fredericton. 45-99.

Fingard, J., Guildford, J., \& Sutherland,D. (1999). Halifax: The First 250 Years. Formac Publishing Company, Halifax. pp. 25-26.

Gascoigne, J. (2014). Encountering the Pacific in the Age of the Enlightenment. Cambridge: Cambridge University Press, 2014.

Gorham, E. (1955). Titus Smith: A Pioneer of Plant Ecology in North America. Ecology, 36 (1): 121.

Hess, S. (2012). William Wordsworth and the Ecology of Authorship: The Roots of Environmentalism in Nineteenth-Century Culture. University of Virginia Press, Charlottesville. pp. 7, 8,115, 223-235.

Holmes, R. (2009). The Age of Wonder: How the Romantic Generation Discovered the Beauty and Terror of Science. Harper Press, London. xvii-xix, pp. 96-103.

Howe, J. (1832). An Opening Address, Delivered at the first meeting of the Halifax Mechanics' Institute, on Wednesday, January 11, 1832 by Joseph Howe. P. J. Holland, Halifax. pp. 7.

Lawson, W. (1972). History of the Townships of Dartmouth, Preston, and Lawrencetown. Belleville: Mika Studio). pp. 157, 206 (note) 215.

McGinnis, M. V. (1999). Bioregionalism. Routledge, New York.

Norman,C.F.(n.d.). Dalhousie University Archives and Special Collections. MS-2-689, Box 75, Folder 5, pp. 53.

O'Connor, R. (2007). The Earth on Show: Fossils and the Poetics of Popular Science, 1802-1856. University of Chicago Press, Chicago. pp.32.

Parrish, S. S. (2006). American Curiosity: Cultures of Natural History in the Colonial British Atlantic World. University of North Carolina Press, Chapel Hill. pp 8.

Piers, H. (1938). The Dutch Village Philosopher: Pioneer Naturalist of Nova Scotia, 1768-1850. Halifax.Proceedings of the Nova Scotian Institute of Science 18(7): 14-22.

Public Archives of Nova Scotia. (n.d.). MG 1, vol. 1773, No. 9. 
Punch,T. (1978). Maple Sugar and Cabbages: The Philosophy of the Dutch Village Philosopher. The Nova Scotia Historical Quarterly, Vol. 8, No. 1 (March 1978): 21.

Smith, T. Jr. (1834). Lecture on Mineralogy Delivered on March 5, 1834 before the Halifax Mechanics' Institute. J. S. Cunnabell, Halifax. pp. 36.

Smith, T. Jr. (1835). Conclusions on the Results on the Vegetation of Nova Scotia, and on Vegetation in General, and on Man in General, of Certain Natural and Artificial Causes Deemed to Actuate and Affect Them. The Magazine of Natural History 8 (56): 642, 660-662.

Smith, T. Jr. (1836a). Education. Acadian Recorder, 13 February.

Smith, T. Jr. (1836b). Botany. Acadian Recorder, 20 February.

Stayner, C. St. C. (1951). The Sandemanian Loyalists. Collections of the Nova Scotia Historical Society 29: 62-123.

Walls, L. D. (2009). The Passage to Cosmos: Alexander von Humboldt and the Shaping of America. University of Chicago Press, Chicago. pp. 9-11, $261,286$.

Wootton, D. (2015). A New History of the Scientific Revolution. HarperCollins, New York. pp. 27-28.

Wulf, A. (2015). The Invention of Nature: Alexander von Humboldt's New World.Alfred A. Knopf.pp.34-36, 57-59, 249-261, 283-297, and 315-334. 